\title{
Countermeasures for Cross-cultural Communication in Commercial Activities Based on OBOR
}

\author{
Junxia Liu ${ }^{1, a}$ \\ ${ }^{1}$ Xi'an FanYi University, Xi'an Shaanxi, 710105 \\ a liujunxia@nwsuaf.edu.cn
}

Keywords: Cross-cultural Communication; Commercial Activities; OBOR

\begin{abstract}
The countries along One Belt One Road (OBOR)are important open areas for China in the new era. The commercial activities between China and the OBOR countries becoming more and more frequent and active. Big challenge which enterprises in business activities faced is cultural differences and conflicts. Based on the analysis of the main obstacles in cross-cultural communication, such as language, values, mode of thinking, cultural stereotypes, etc., recommendations are proposed that China should promote good image, identify and respect the common culture of the world in business activities, enterprises should focus on cross-culture and language training, and strengthening the intercultural management.
\end{abstract}

\section{Introduction}

410 million U.S. dollars in total foreign trade volume has been produced between China and One Belt One Road(OBOR) countries, it was accounting for more than a quarter in the same period. Nearly 50 billion U.S. dollars has been directly invested with the OBOR countries by China from 2015 to 2017, which account for almost $10 \%$ of the total foreign investment amount in the same period. Business activities of China's enterprises and organizations become more and more active based on OBOR. And it makes the awareness of cultural diversity and the demand of communication in intercultural grow up. The effective intercultural communication has been an important part in foreign trade activities. And good communication is the premise of promoting mutual trust and focusing on development between China's enterprises, organizations and countries along the OBOR. Seeking and solving problems of cross-cultural communication has great practical significance to carry out China's foreign trade activities below the OBOR initiative.

Table 1 China's investment and cooperation in the countries along the OBOR

\begin{tabular}{cccc}
\hline Year & No. of countries & ODI (100 million Yuan) & Share of the total \\
\hline 2015 & 48 & 120.3 & - \\
2016 & 53 & 145.3 & $8.5 \%$ \\
2017 & 59 & 143.6 & $12 \%$ \\
2018 (month 1-2) & 50 & 22.8 & $12.2 \%$ \\
\hline
\end{tabular}

Source: Website of the Ministry of commerce of the People's Republic of China

\section{The Significance of Cross-cultural Communication in Foreign Trade Activities}

There are 65 countries along OBOR, and all of these countries have different sorts of custom and cultural. Multi-country collaboration require intercultural conversation to deepen understanding and trust with each other and strengthen communication among various civilizations to form the cornerstone of seeking common ground while shelving differences and symbiotic linkage development. Cross-cultural exchange plays a role of catalyst in the communication between China and countries along the OBOR, and the pattern of carrying out various cultural exchanges, mutual respect, mutual appreciation, mutual understanding and inclusion is gradually building up at present. 
The Global Investment Risk Analysis Report of China Export \& Credit Insurance Corporation's in 2017 shows that Chinese enterprises' direct investment on non-financial along the OBOR countries is $12.3 \%$ of the total foreign non-financial investment in January to September 2017, which is $4.2 \%$ higher than the proportion in 2016. Under this trend, enterprises in countries along the OBOR are facing challenges about multinational operations and management. Transnational cultural communication is the important precondition for the survival of international enterprises and organizations. The research of World Bank Group shows that the main challenge for the 150 Chinese enterprises that make foreign direct investment is the cultural conflict. And according to the author's investigation and interview with foreign-related enterprises in some cities along the Longhai-Lanxin's Railway in China, here drawing a conclusion that intercultural communication is the significant factor in the smooth conduct of international business activities. The business activities of domestic enterprises along the Belt and Road are facing four major obstacles, including language, law, finance and government. Some of the enterprises fail to "going aboard" are not caused by direct risks, but caused by indirect risks which including community relations, public governance capability, stakeholder communication, transparency, environmental responsibility, etc..

\section{Obstacles in Foreign Business Activities of the BELT and ROAD}

Language Barrier. Language is the outer shell of thinking, the foundation of communication, and the link between civilizations. The B\&R involves more than 50 official languages and thousands of minority languages. Diverse language services are of great help to economic development. According to the information: " $10 \%$ of Switzerland's GDP benefits from linguistic diversity, and 18 million non-Spanish native speakers learn Spanish, and the industry output value associated with Spanish up to 150 billion euros each year. " [2] Due to the large differences in the level of economic development and education among countries along the $B \& R$, differentiated language has already become an important obstacle to achieve cross-cultural business communication without conflicts. Misuse or ignorance of the underlying emotional meaning hidden behind words can have a negative impact on business activities. However, more business communication should possess "temperature" and be a face-to-face communication. This kind of communication will bring sense of trust and participation which cannot be replaced by any machine.

Value Divergence. Value divergence is the main cause of cultural conflicts in transnational business activities. These conflicts are the different understandings of different cultural on the relationship between human and human, human and natural, human and society, human reality and human cultural historicity, which performance in international business activities. ${ }^{[3]}$ This profound cultural difference is reflected in the economic operation of international commerce, resulting in the formation of commercial conflicts. Four civilizations and multiple languages co-exist along the OBOR, and such a huge cultural divergence is extremely prone to misunderstanding. It is necessary to select important countries as supporting points in the external business communication, analyze and study their values, and avoid commercial conflicts in economic exchanges. Western value systems promote individualism and focus on material pursuits. They believe that work is self-conscious rather than forced, respecting rules and systems, and acting bluntly. China's value system advocates collectivism. The situation of Central Asia and South Asia along the OBOR is more complicated. Central Asian countries have always been the intersection of Eastern and Western cultures. Turkic culture, Buddhist culture, Persian culture, Islamic culture, Slavic culture, and Western culture have a profound impact on Central Asia, and people's ideology is more complex. In addition to this, South Asia is greatly influenced by Buddhist culture. We must fully understand and study it in order to control the potential risks of the enterprises.

Thinking Modes Divergence. Thinking mode is the experience and habit in the field of cognition which was formed and accumulated in the course of long history. It forms a certain mode through thought, and then forms a specific mode of thinking. Different countries have different thinking modes. In Germany, for example, their thinking a straight-line and is abstract. They focus on directness, frankness and truth-seeking in economic exchanges and cooperation and like to 
express their own point of views directly. The countries with straight-line thinking are very direct in business negotiations. They go into specific clauses at the very beginning of the negotiations, while the Chinese discuss principles firstly and then pragmatic. Therefore, the Germans found it hardest to conduct business negotiations with the Chinese. In the eyes of Germans, what the Chinese people think that the style of conversation that fully complies with the communicative context is assessed as rhetorical, tortuous and tedious (Fig. 1). ${ }^{[2]}$ The countries along the OBOR are multi-ethnic and multi-religious. Their modes of thinking are influenced by the East and the West but maintain their own national characteristics. Undoubtedly, the differences of thinking modes among the various nations and people must be the hidden barrier to our business activities with the countries along the line.

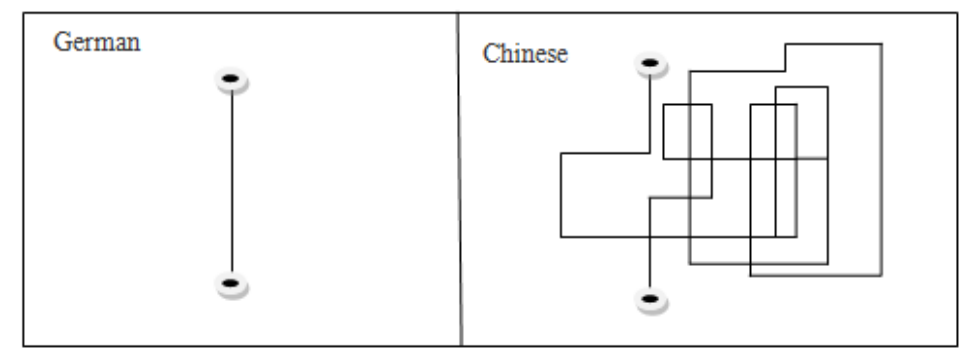

Figure 1. Finite Differences in the expression of views

Cultural Stereotype. Cultural stereotype is a fixed-dimensional thinking mode of a nation's cultural members in the theory of nation and culture. When there is a negative attitude to his or her culture, cultural stereotype will be translated into cultural bias. Under normal circumstances, people are accustomed to using their own country's cultural values to measure the cultural phenomenon in other countries, and thus to determine the "normal" and "abnormal". That is, being similar to my own cultural standards and concepts is "normal". On the contrary, it is "abnormal". When cultural bias is accompanied by a strong cultural mentality, cultural superiority and personal feelings confrontation, cultural bias can easily turn into cultural discrimination. Under such circumstances, cultural superiority and the strong cultural mentality are highly exclusive. When there is asymmetry and difference in culture or the value of confrontation arises, it will subjectively and maliciously explain his culture. The countries along the OBOR have different religions and different cultures. China need to learn, understand and respect the culture of other countries in foreign business exchanges, and avoid judging business practices in other countries from the standpoint of our own.

\section{Suggestions for cross-cultural exchanges in OBOR foreign Business Activities}

Attach Importance to Promote a Good Image. At present, Chinese enterprises' "going abroad" faces a complicated external environment. Foreign investment is under the pressure of protectionism heating up. The conflict between Chinese and foreign cultures and interests is inevitable. Therefore, it brings about a greater negative impact on Chinese enterprises. Under the background of China's continuous optimization of industrial layout, great strides in products, talents, technology, standards and culture, and mutual benefit and inclusive sharing with the countries along the OBOR, our government and enterprises should commit themselves to the establishment and promotion of good images. Like the "China National Image Video" and "The Image of China's Small Enterprises", they have all achieved good results. This is a window for the outside world to understand China. To establish a good image, the government should also promote to establish a credit system for foreign economic cooperation.

Recognize and Respect World Common Culture. In the communication and exchange of foreign business activities, there are some values and codes of conduct that transcend the boundaries of countries, nations and ideologies, which are recognized by most people in the world and have become common features of human culture and civilization. We need to maintain identity to the world accredited value orientation and behavior, while respecting cultural commonality and also requiring both sides of cross-cultural exchanges to transcend the thinking mode of self-centered 
culture and the habits of cultural viewing, to treat and respect multi-level commonalities and differences that existing among cultures and nations with cultural tolerance so as to alleviate cross-cultural conflicts and promote people's intercultural communication. ${ }^{[5]}$ Communication leads to consensus, and understanding leads to consensus. The concept of "Human Destiny Community" has been written into UN resolutions one after another, UN Security Council Resolution on Afghanistan and UN Human Rights Council Resolution ${ }^{[6]}$ are an important manifestation of respect and recognition. On the basis of identity and mutual respect, all countries along the "OBOR" can make business communication contain cultural differences with each other.

Pay Attention to cross-cultural and Language Training. Any enterprise "going abroad" needs to adapt to the local society and culture. Cross-cultural training must be promptly followed up. Enhancing the response and adaptability of corporate managers and employees to different cultures, promoting mutual understanding among people in different cultural backgrounds, guiding employees to look at and solve problems from different perspectives, and making use of the differences between different cultures to create a turning point for the development of enterprises through cross-cultural training. At the same time, cross-cultural training should also focus on language training.

Enterprises Needs to Deepen cross-Cultural Management. Cases show that cross-cultural management is a big challenge. The challenge is that enterprises that "going aboard" will have to hire a large number of local staff and then copy their domestic management methods overseas. It is very difficult to achieve good results. So the enterprises must be in-depth beforehand, during and after the whole process of deep participation. Companies need to do comprehensive and in-depth research when formulating multinational business strategies, and try to minimize and avoid the negative influences of cultural differences. Enterprises in the formulation of strategies should focus on the integration of culture. Only to integrate the country's own culture, the target market country culture and the corporate culture, can enterprises deeply adapt to the market, thereby expanding the market. Enterprises can organize activities to create conditions that facilitate the exchange of experience between Chinese and foreign managers to promote coordination and cooperation between the enterprises and people of different cultural backgrounds.

\section{Acknowledgement}

This work was supported by the 13th five-year plan research Fund of education science in Shaanxi province (SGH17H492) and XFU scientific research team Fund (XFUKYTUA01), There is no conflict of interest.

\section{References}

[1] Liu Bingya. Cross-cultural exchange for the "Belt and Road" played a new international cooperation in the music movement [DB/OL].2017-05-17.

http: //review.jschina.com.cn/gdpl/201705/t20170517_515520.shtml.

[2] He Xianfeng. "Belt and Road" construction to promote the language industry warming [N]. Economic Daily. July 27, 2017.

[3] Dou Weilin. On the important role of values in international business activities [J].Journal of East China Normal University (Social Science Edition), 1999 (2): 88-91.

[4] Liang Z. Cross-cultural Issues in Sino-German Economic Cooperation [J].Journal of Qingdao University .2001 (12): 79-86.

[5] Wang Zhiqiang. On the Intercultural Understanding of Predicament Types - A Case Study of Sino-German Cultural Behaviors [J] .British Studies .2011 (3): 64-80.

[6] Wang Si-min, Li Sheng-ming. "One Belt and One Road Initiative": China's Political Confidence, Economic Integration and Cultural Inclusion [N]. PR World .2017 (5): 18-23. 